\title{
Water and sediment quality survey of threatened and endangered freshwater mussel habitat in the Chipola River Basin, Florida
}

\author{
Jon M. Hemming ${ }^{1, *}$, Parley V. Winger ${ }^{2}$, Heath Rauschenberger ${ }^{3}$, Karen Herrington ${ }^{1}$, \\ Peter Durkee $^{1}$, Dan Scollan ${ }^{1}$
}

${ }^{1}$ US Fish and Wildlife Service, 1601 Balboa Avenue, Panama City, Florida 32405, USA

${ }^{2}$ US Geological Survey, Patuxent Wildlife Research Center Athens, Athens, Georgia 30602, USA

${ }^{3}$ US Fish and Wildlife Service, 6620 Southpoint Drive South, Jacksonville, Florida 32216-0958, USA

\begin{abstract}
Reduced habitat quality may be contributing to the decline of freshwater mussels in southeastern rivers. As part of an ongoing evaluation of the quality of freshwater mussel habitat in Gulf of Mexico coastal rivers, the Chipola River was assessed during 2006 and 2007. Sediment samples were collected at 8 sites along the Chipola River on May 2 and 3, 2006, and analyzed for contaminants and tested in the laboratory for toxicity to Hyalella azteca using $29 \mathrm{~d}$ exposures to solidphase sediment and $96 \mathrm{~h}$ exposures to sediment porewater. In addition, benthic macroinvertebrate populations were sampled at each site. Using the sediment quality triad approach (chemistry, toxicity and in situ benthic assemblages) to assess habitat quality, 3 sites $(1,4$ and 8 ) were shown to be impaired, with Site 4 being the most impaired site. $H$. azteca survival in porewater exposures was reduced, and trace elements were elevated in sediments at these sites; however, concentrations were not considered exceedingly high. Water quality samples collected did not violate the State of Florida's water quality standards. The lack of concordance among the test metrics (in situ benthic assemblages were not impaired) at these sites suggests marginal habitat impairment.
\end{abstract}

KEY WORDS: Water quality $\cdot$ Sediment quality $\cdot$ Macroinvertebrates $\cdot$ Chipola River $\cdot$ Freshwater mussels

\section{INTRODUCTION}

Animals classified as freshwater mussels (family Unionidae) have been described as vital components of aquatic ecosystems, both ecologically and economically. These bivalve mollusks can have a large influence on total benthic biomass and are important participants in nutrient cycling and sediment dynamics (Newton 2003). However, both density and species diversity of these organisms in North America have declined to a large extent during the past century (Newton 2003). Unionid mussels are one of the most rapidly declining faunal groups in the United States and constitute the largest group of federally listed endangered or threatened invertebrates. Over $70 \%$ of the 297 species and subspecies are listed as endangered, threatened, or of special concern (Williams et al. 1993, Neves et al. 1997).

Although the causal factors for unionid declines are largely unknown, contributing factors may include sedimentation, disease, predation, changes in fish communities (used as larval hosts), alterations of river channels, commercial exploitation, environmental contamination, and introduction of exotic species (Fuller 1974, Havlik \& Marking 1987, Bogan 1993, NNMCC 1998, Augspurger et al. 2003, Mummert et al. 2003, Newton 2003). However, most studies that have reported unionid declines provide only anecdotal evi- 
dence of causal mechanisms (Newton et al. 2003). Although causation has not been established, exposure to contaminants may have contributed to significant mussel losses (Newton 2003). Descriptions of localized mortality have been provided for chemical spills and other discrete point source discharges; however, range-wide decreases in mussel density and diversity may have resulted from the more insidious effects of chronic, low-level contamination (Naimo 1995, Newton 2003, Newton et al. 2003). As stated by Augspurger and others (2003), freshwater mussel experts often report chemical contaminants as factors that are limiting to unionids (Richter et al. 1997). They also noted the differential sensitivity of freshwater mussels that results in tolerances to some organic solvents and pesticides (Keller 1993, Keller \& Ruessler 1997), but also high sensitivity of early life stages to contaminants such as chlorine (Goudreau et al. 1993), metals (Keller \& Zam 1991, Jacobson et al. 1993), and ammonia (Horne \& McIntosh 1979, Goudreau et al. 1993).

There has recently been much progress in the area of mussel ecotoxicology (Augspurger et al. 2007). There has been particular focus on the development and use of glochidia and juvenile mussel-specific toxicity tests (ASTM 2007, Wang et al. 2007a). Although not yet available when the present evaluation was designed and proposed, these mussel-specific tests have shown under which circumstances traditional surrogates are less sensitive to certain toxic exposures than some mussel life stages (Bringolf et al. 2007a,b,c, Newton \& Bartsch 2007, Wang et al. 2007b,c, Gillis et al. 2008). This will have large implications for the re-assessment of the protectiveness of water quality criteria where unionid mussels are concerned (Augspurger et al. 2007, March et al. 2007).

Newton (2003) described aspects of unionid life history that may make them important sentinels of habitat integrity. Adult mussels are large-bodied, longliving (30 to $130 \mathrm{yr}$ ), sediment-dwelling invertebrate organisms. The exposure to the surrounding environment is greatly enhanced by their filter-feeding strategy. They are consequently exposed to contaminants that have been dissolved in water, associated with suspended particles, and deposited in bottom sediments (Newton 2003). Unfortunately, most toxicity data for freshwater mussels are from water-only exposures, despite reports that sediment-associated contaminants contributed to declines of mollusks in several large rivers (Sparks \& Sandusky 1981, Wilson et al. 1995).

As described in the United States Fish and Wildlife Service (hereafter 'Service') freshwater mussel recovery plan (USFWS 2003), the fat threeridge Amblema neislerii, shinyrayed pocketbook Lampsilis subangulata, Gulf moccasinshell Medionidus penicillatus, Ochlockonee moccasinshell Medionidus simpsonianus, oval pigtoe Pleurobema pyriforme, Chipola slabshell Elliptio chipolaensis, and purple bankclimber Elliptoideus sloatianus freshwater mussel species have suffered population declines. According to the Service's recovery plan, these species of the eastern Gulf Slope rivers were known to have rich populations. The reduction and fragmentation of the freshwater mussel populations in these systems have resulted in species vulnerability to extinction. These rivers drain the Apalachicolan Region, which extends from the Escambia River eastward to the Suwannee River system and includes portions of southeast Alabama, westcentral and southwest Georgia, and north Florida. Collectively, these rivers comprise the area's predominant drainage.

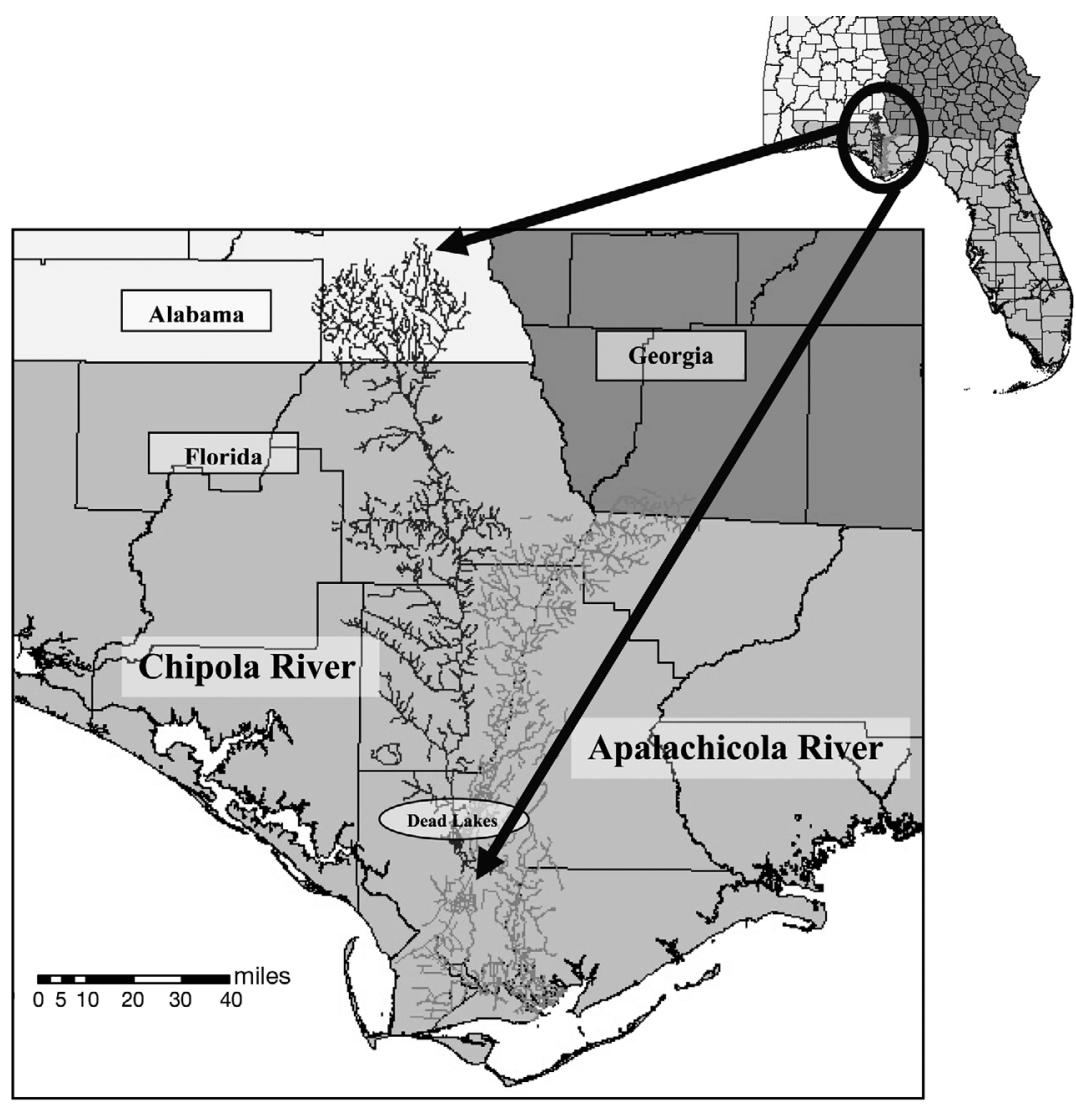

Fig. 1. Location of the Chipola River flowing south from Alabama to the Apalachicola River in Florida 
Within the eastern Gulf Slope drainage, the Chipola River Basin stretches from Alabama southward to the eastern Florida panhandle (Fig. 1). The Chipola drainage (812000 acres) provides important habitat for 4 federally listed endangered and 1 federally listed threatened freshwater mussels, the Chipola slabshell, fat threeridge, Gulf moccasinshell, oval pigtoe, and shinyrayed pocketbook. Species richness (number of federally listed threatened or endangered species) of imperiled taxa appears to remain steady; however, abundance and distribution of these species cannot be ascertained from the available data.

The goal of the present study was to aid the recovery effort for these mussels by examining factors potentially affecting their continued existence, impacts of present threats, habitat improvement needs, and protection from further threats. To address these points, information on water and sediment quality was gathered and used to rank sites needing protection, restoration, and/or eventual reintroduction of listed mussel species.

\section{MATERIALS AND METHODS}

Ambient water quality. Ambient water quality was characterized for 8 sites along the Chipola River, distributed from the headwaters to near the mouth of the Chipola River (Fig. 2). Sites were selected to correspond with historical mussel survey locations according to the United States Fish and Wildlife Freshwater

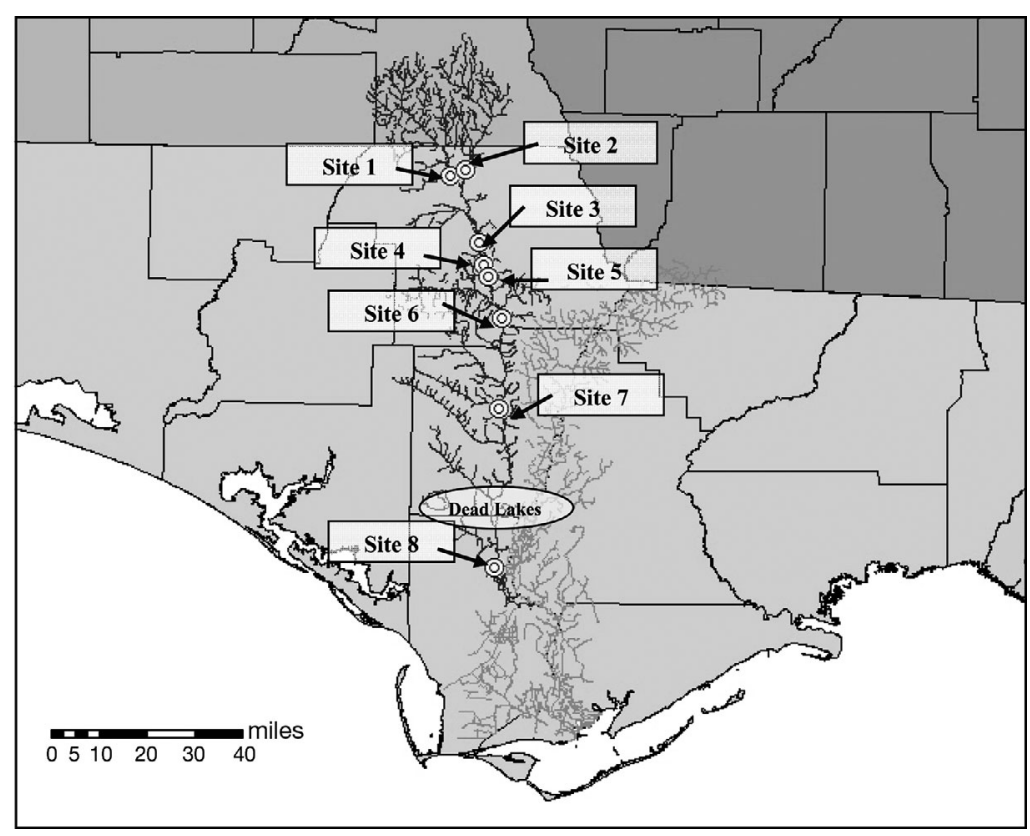

Fig. 2. Location of United States Fish and Wildlife Service water quality sampling sites (@) on the Chipola River from 2006 to 2007
Mussel Database. Water column grab samples were taken from each site during high water, low water, and mean water discharge. Sampling was conducted during 2006 and 2007.

Water quality parameters included dissolved oxygen $\left(\mathrm{mg} \mathrm{l}^{-1}\right)$, temperature $\left({ }^{\circ} \mathrm{C}\right), \mathrm{pH}$ (standard units, $\left.\mathrm{SU}\right)$, chlorophyll a ( $\mathrm{chl}$ a) concentration $\left(\mu \mathrm{g} \mathrm{l}^{-1}\right)$ as calculated from fluorescence, turbidity (NTU), specific conductance $\left(\mu \mathrm{S} \mathrm{cm}^{-1}\right.$ at $\left.25^{\circ} \mathrm{C}\right)$, alkalinity $\left(\mathrm{mg} \mathrm{CaCO} \mathrm{Cl}^{-1}\right)$, and hardness (mg $\mathrm{CaCO}_{3} \mathrm{l}^{-1}$ ). Dissolved oxygen, temperature, conductivity, $\mathrm{pH}$, chl a concentration and turbidity were monitored in the field using a YSI Model 6600 multiparameter data logger. The instrument included a rapid pulse dissolved oxygen probe, conductivity/ temperature probe, fluorescence-derived chl a probe, nephlometric turbidity probe, $\mathrm{pH}$ probe, and calculated salinity and total dissolved solids. Readings were taken 15 to $30 \mathrm{~cm}$ from the river bottom at each site. The data were recorded to a YSI 650 multiparameter display system. The remaining analyses were performed on aliquots from 11 samples taken at each site. Alkalinity and hardness were measured in the laboratory with a HACH digital titrator, Model 16900. Protocols for sample collection, preservation, and holding times followed standard methods or the manufactuer's guidelines.

Statistical analyses on water quality data were performed using SAS Version 9.1.3 (SAS Institute 2007). Statistically significant differences were accepted at $\alpha=0.05$. Data were analyzed with parametric analysis of variance (ANOVA) when assumptions of normality and homogeneity were met. The TukeyKramer honestly significant difference (HSD) multiple comparison tests (MCT) were used when differences were found. When parametric assumptions were not met, the non-parametric Kruskal-Wallis analysis was used, with a ranked TukeyKramer HSD MCT when differences were found. Associations were examined via Pearson correlation analysis for parametric data and Spearman correlation analysis for non-parametric data.

Sediment quality. Most anthropogenic compounds (inorganic and organic) entering aquatic systems eventually accumulate in the sediment matrix, which serves not only as a sink for these contaminants, but also as a potential source. Because of these unique characteristics, assessments utilizing the sediment matrix have been shown to provide useful information in the process of categorizing the quality of habitat in aquatic systems (Winger \& Lasier 1995). Using 
the preponderance of evidence approach, examination of multiple lines of evidence provides a robust means of characterizing sediment quality. This evaluation of habitat quality in the Chipola River utilizes sediment chemistry (contaminant residues in the sediment), toxicity elicited through exposure to the sediment in the laboratory, and an evaluation of the in situ benthic populations. These components provide the foundation for the sediment quality triad that has been shown to provide useful information for the categorization of sediment quality (Chapman 1990).

Sediment samples were collected from the same 8 water quality monitoring sites on May 2 and 3, 2006. Samples were collected with a stainless-steel petite Ponar grab. Sampling equipment was thoroughly rinsed between sites. Then, 3 to 4 grab samples from the top 10 to $15 \mathrm{~cm}$ of bottom sediment were placed in a stainless steel pan, where these sediments were homogenized with a stainless steel spoon. Sticks and grass were removed during the homogenization process. Aliquots $(500 \mathrm{ml})$ of the homogenized sediment sample were placed into glass jars, one for metal analyses and another for organic contaminant analyses. Approximately $4 \mathrm{l}$ of sediment from each site were transported to the laboratory for toxicity testing and sediment characterization. Sediment samples were held in the dark at $4^{\circ} \mathrm{C}$ pending testing and analyses.

Toxicity testing. In the laboratory, sediments were tested for toxicity, and physical and chemical characteristics were determined. Toxicity was assessed following procedures described by Ingersoll et al. (1994), except that the exposure period was increased from the described 10 to $28 \mathrm{~d}$, to provide a more sensitive measure of chronic effects. Prior to testing, each sample was re-homogenized and two $100 \mathrm{ml}$ aliquots were taken: 1 for physical characterization and acid volatile sulfide and simultaneously extracted metals, and 1 for metal analyses. From each sediment sample and the laboratory control sediment, 5 replicate samples were prepared for toxicity testing. The laboratory control sediment consisted of sand conditioned for $2 \mathrm{wk}$ in moderately hard water and a mixture of Selenastrum (algae) and YCT (yeast, Cerophyl, and trout chow). Each replicate consisted of $100 \mathrm{ml}$ of sediment and $175 \mathrm{ml}$ of laboratory-reconstituted water placed in a $300 \mathrm{ml}$ high-form beaker with a notch in the lip and covered with a stainless steel mesh $(250 \mu \mathrm{m})$. The reconstituted water was prepared following guidelines given in Ingersoll et al. (1994) and consisted of deionized water, calcium sulfate, calcium chloride, magnesium sulfate, sodium bicarbonate, and potassium chloride, providing a hardness of $100 \mathrm{mg} \mathrm{l}^{-1}, 70 \mathrm{mg} \mathrm{l}^{-1}$ alkalinity, $350 \mu \mathrm{S} \mathrm{cm}^{-1}$ conductivity, and a $\mathrm{pH}$ of 8 . The 5 replicates were randomly positioned in the staticrenewal testing system that replaced the overlying water twice daily (Zumwalt et al. 1994). Ten 7 d old Hyalella azteca (Crustacea: Amphipoda) were placed into each test chamber. Test chambers were maintained at $23 \pm 1{ }^{\circ} \mathrm{C}$ under wide-spectrum fluorescent lights with a 16:8 h light:dark regime. Animals were fed $1.5 \mathrm{ml}$ YCT (1.8 $\left.\mathrm{g}_{\text {solids }} \mathrm{l}^{-1}\right)$ daily. Solid-phase sediments were tested under static-renewal conditions, with 2 renewals daily (Ingersoll et al. 1994). Test endpoints for the $28 \mathrm{~d}$ static-renewal tests on sediments were survival and growth. Growth was determined by measuring the length of a projected image of H. azteca using a microscope slide projector calibrated with a stage micrometer. Chemistry of the overlying water was monitored during the test, including temperature, dissolved oxygen, $\mathrm{pH}$, alkalinity, hardness, conductivity, and ammonia.

In addition to testing solid-phase sediments, sediment porewaters were also evaluated for toxicity using 96 h static exposures (Winger \& Lasier 1995). Porewater was isolated from the sediment using vacuum extractors (Winger \& Lasier 1991). Ten extractors (each consisting of a $60 \mathrm{cc}$ syringe, airline tubing, and a fused glass air stone) were inserted into each sediment sample, and a vacuum was applied by extending and bracing the plunger. Approximately $300 \mathrm{ml}$ of porewater was extracted from each sediment sample. A $20 \mathrm{ml}$ aliquot for analyses of trace elements was filtered through a $0.45 \mu \mathrm{m}$ filter (sterile Fisherbrand syringe filters with a polytetrafluoroethylene [PTFE] membrane) and acidified with ultra-pure nitric acid to a $\mathrm{pH}$ of $<2.0$, to prevent the solution from adhering to the vessel walls. The remaining porewater was aerated for $15 \mathrm{~min}$ prior to test initiation. Five replicates of each sample were prepared for testing, and each consisted of $20 \mathrm{ml}$ of porewater, ten $7 \mathrm{~d}$ old H. azteca, and a $1 \mathrm{~cm}^{2}$ of Nitex netting $(275 \mu \mathrm{m})$ in a $30 \mathrm{ml}$ plastic cup. The animals were not fed during the test. The test endpoint for the $96 \mathrm{~h}$ static exposures to porewater was survival. The same basic chemistry parameters measured in the overlying water in the solid-phase sediment tests were measured in the porewater after aeration.

Sediment analyses. Sediments were characterized by measuring percentage of organic content, particle size analyses, acid volatile sulfides (AVS), and the simultaneously extracted metal concentrations (SEM). Organic content was estimated by loss on ignition at $430^{\circ} \mathrm{C}$ for $4 \mathrm{~h}$ (Davies 1974). Particle size analyses were determined using methods described by Miller \& Miller (1987), except that coarse organic material was measured by loss on ignition and subtracted from the total. AVSs were measured following procedures described by Brouwer \& Murphy (1994). Simultaneously extracted metals $(\mathrm{Cd}, \mathrm{Cu}, \mathrm{Hg}, \mathrm{Ni}, \mathrm{Pb}, \mathrm{Zn})$ were measured in the AVS digestates after they were passed 
through a $0.45 \mu \mathrm{m}$ nylon filter. Trace elements (As, $\mathrm{Ba}, \mathrm{Ca}, \mathrm{Cd}, \mathrm{Cr}, \mathrm{Cu}, \mathrm{Fe}, \mathrm{Hg}, \mathrm{K}, \mathrm{Mg}, \mathrm{Mn}, \mathrm{Na}, \mathrm{Ni}, \mathrm{Pb}, \mathrm{Se}$, $\mathrm{Zn}$ ) in porewater and the AVS digestates were analyzed by inductively coupled plasma mass spectrometry (ICP-MS). Total organic carbon in porewater was determined after acidification with a Leco CR-412 carbon analyzer, calibrated with calcium carbonate. Chloride and sulfate were measured using an ion chromatograph.

Quality assurance/quality control. Analyses were within acceptable limits for precision and accuracy based on quality assurance data that included blanks, duplicates, spikes, and standard samples. The ICP-MS instrument detection limits for trace elements were as follows (in $\mu \mathrm{g} \mathrm{l}^{-1}$ ): Ag, 0.054; $\mathrm{As}, 0.183 ; \mathrm{Ca}, 12.78$; $\mathrm{Cd}$, 0.018; Cu, 0.129; Cr, 0.918; Fe, 2.89; k, 13.07; Hg, 0.009; Mg, 0.135; Mn. 0.213; Na, 0.033; NI, 0.177; Pb, 0.015; $\mathrm{Se}, 0.609$; and $\mathrm{Zn}, 0.528$. The limit of quantitation was established as 3 times the lower limit of detection. The mean relative standard deviation between duplicate samples of porewater was 8.57 , with a high of $31.51 \%$ for $\mathrm{Sn}$ and a low of $0.00 \%$ for $\mathrm{Cr}, \mathrm{Se}, \mathrm{Ag}$, and $\mathrm{Cd}$. Blanks were below the instrument detection limits, and recovery from spiked samples averaged $72 \%$. The percent recoveries for the field samples were: Ag, 104.3; As, 101.1; Cd, 105.5; Cu, 97.12; Cr, 94.7; Fe, NA; Hg, NA; Mg, NA; Mn, 100.9; Ni, 95.9; Pb, 117.6; Se, NA; and $\mathrm{Zn}, 96.5 \%$. The concentrations listed were not corrected for the percent recoveries. For sediments, the mean relative standard deviation between duplicates was $10.74 \%$, with a high of $42.85 \%$ for $\mathrm{Cd}$ and a low of $0.57 \%$ for Na. The relative standard deviation for laboratory replicates was $7.6 \%$.

Shapiro-Wilks tests for normality were performed on the data. ANOVA and Dunnett's pair-wise tests were then used to evaluate differences $(p<0.05)$ with the controls. Spearman rank correlations among variables and test parameters were determined. All statistical analyses were performed using Statistical Analysis Systems (SAS Institute 1990).

Benthic macroinvertebrates. In addition to sediment samples, benthic organisms were also collected at each site. Aquatic dip nets were used to collect benthic organisms from all available habitat types at each site shallow enough to wade, typically sites found upstream. However, downstream sites were in the larger river area and therefore were collected by boat via Ponar grabs of bottom sediments or using an aquatic dip net to sample snags and patches of aquatic vegetation. Three samples of at least 100 benthic macroinvertebrate organisms were picked live from white sorting pans using forceps and pipettes. Benthic samples were preserved using a mixture of ethanol, methanol, glyoxal, iodine, propionic acid, and formalin. In the laboratory, benthic organisms were identi- fied to the lowest practical taxonomic unit (generally genus) using the following taxonomic keys: Parrish (1975), Pennak (1978), Brigham et al. (1982), Pluchino (1984), Daigle (1991, 1992), Epler (1996, 2001, 2006), Pescador \& Richard (2004), and Thompson (2004). Metrics used in the assessment of benthic community structure were the total number of taxa, sequential comparison index (Cairns \& Dickson 1971), ShannonWeaver diversity (Poole 1974), and percentage comprised by the 3 most numerically dominant taxa (Plafkin et al. 1989).

Evaluation of potential risk. A risk score estimating the relative threat that ambient conditions may cause sediment-dependent freshwater species was derived with a modification of the approach used by Hemming et al. (2006). This habitat evaluation included water quality with the traditional sediment quality triad approach as described by Chapman (1990), but it lacked the potential sophistication provided by more recent approaches (Chapman 1996, Chapman et al. 2002, Chapman \& Anderson 2005, Chapman \& Hollert 2006, McPherson et al. 2008).

In this evaluation, a risk score was estimated for each of the following categories: ambient water quality, sediment toxicity (porewater and whole sediment), sediment metals, porewater metals, sediment general chemistry, porewater general chemistry, and relative in situ benthic macroinvertebrate community health. Each category had multiple occasions to score risk points.

The risk to aquatic life was assigned for overall ambient water quality, for the parameters dissolved oxygen, temperature, $\mathrm{pH}$, chl a concentration turbidity, and conductivity. Each violation of a State of Florida water quality standard (FAC 2004) or federal water quality criterion (USEPA 2002) constituted an individual score of 1 . Risk associated with sediment toxicity for aquatic life was estimated from porewater and solid-phase exposures of Hyalella azteca (acute and chronic assays). A score of 1 was assigned for significant differences from the control for each test, and scores for all tests were summed by site. Risk via exposure to whole sediment metals was estimated by comparison of sediment metal analytical data to reference values such as those of MacDonald et al. (2000). Each value exceeding the sediment quality guidelines constituted an individual score of 1. Similarly, porewater metal risk was estimated by comparison of metal porewater constituents to State of Florida surface water quality standards or federal water quality criteria. Violations received a score of 1 each. Sediment quality risk to aquatic life stemming from general sediment chemistry was based on reference values for relative sediment quality. Violations of the guidelines provided by Di Toro et al. (1992) 
received a score of 1 each. Finally, potential risk to aquatic life associated with sediment porewater chemistry was determined by comparison to the State of Florida surface water quality standards or federal water quality criteria or pertinent recommendations thereof (Augspurger et al. 2003). Violations received a score of 1 each.

\section{RESULTS AND DISCUSSION}

\section{Ambient water quality}

According to historic average flows estimated by measures taken by the United States Geological Survey gage on the Chipola River at Altha, Florida (USGS 02359000), most water quality sampling $(n=6)$ was conducted in low flow conditions (553 to $670 \mathrm{~cm}^{3} \mathrm{~s}^{-1}$ ); however, 1 sample was taken at both the median flow condition $\left(1180 \mathrm{~cm}^{3} \mathrm{~s}^{-1}\right)$ and a higher flow condition $\left(1910 \mathrm{~cm}^{3} \mathrm{~s}^{-1}\right)$. Drought conditions prevented further sampling under median or higher flow conditions.

Water quality on the Chipola River was unremarkable during the sampling sessions. Although statistically significant differences were observed among the sites for dissolved oxygen, chl a concentration, turbidity, specific conductance, alkalinity, and hardness, none appeared to be ecologically relevant. No parameters were observed to be in violation of State of Florida or State of Alabama water quality standards. Temperature ranged from 9.2 to $30.7^{\circ} \mathrm{C}$ throughout the year. Specific conductance ranged from 76 to $297\left(\mathrm{uS} \mathrm{cm}^{-1}\right.$ at $25^{\circ} \mathrm{C}$ ) over the course of the river. The dissolved oxygen concentration was high, ranging from a low of $6.9 \mathrm{mg} \mathrm{l}^{-1}$ to supersaturation. However, it should be noted that all sampling was conducted during the day, and nocturnal dissolved oxygen depressions would not have been recorded. Hydrogen ion concentration $(\mathrm{pH})$ was measured in the Chipola to be from 7.1 to 8.3 in standard units during the sampling year. Relative turbidity (range river-wide $<3.0$ to 31.2 nephelometric turbidity units [NTUs]) seemed to vary more when compared to relative chl a concentration $(0.3$ to $8.2 \mu \mathrm{g}$ $\mathrm{l}^{-1}$ as estimated via fluorescence). Neither turbidity nor chl a concentration (as estimated by community imbalance) violated water quality standards. Alkalinity was measured to be from 11 to $132 \mathrm{mg} \mathrm{CaCO} \mathrm{l}^{-1}$ during the study, and hardness was very similar, ranging from 50 to $131 \mathrm{mg} \mathrm{CaCO} \mathrm{I}^{-1}$.

Almost all water quality parameters showed a significant correlation with the discharge rate as estimated by the United States Geological Survey gage on the Chipola River at Altha, Florida (USGS 02359000), with the only exception being $\mathrm{pH}$. The correlation was likely influenced by the low flow water quality condi- tion being represented by 6 replicate measures site ${ }^{-1}$, but the median and high flow measures being represented by 1 sample site ${ }^{-1}$. The survey was designed to capture more median and high flow events to better represent variable associations; however, drought conditions prevented this.

Although the associations were statistically valid, the correlation coefficients (showing degree of association, between 0 and 1.0) were not particularly high for specific conductance $(\mathrm{r}=-0.407)$, dissolved oxygen concentration $(r=0.304)$, hardness $(r=-0.388)$, alkalinity $(\mathrm{r}=-0.512)$, or turbidity $(\mathrm{r}=0.495)$. Stronger associations with discharge rate were observed for both temperature $(\mathrm{r}=-0.727)$ and chl a concentration $(\mathrm{r}=$ 0.632). Other noteworthy significant correlations included those between water clarity and dissolved solids. For example, chl a concentration was associated with specific conductance $(\mathrm{r}=-0.787)$, alkalinity $(\mathrm{r}=$ $-0.831)$, and hardness $(r=-0.857)$. Similar associations were also observed for turbidity and specific conductance $(\mathrm{r}=-0.664)$, turbidity and alkalinity $(\mathrm{r}=-0.718)$, and turbidity and hardness $(r=-0.614)$. Another significant association worth noting was between turbidity and chl a concentration $(r=0.704)$, which may indicate that the water clarity of the Chipola River is driven by both organic and inorganic contributions. However, no association was observed between dissolved oxygen concentration and chl a concentrations that may have explained primary productivity related to the organic component.

\section{Sediment quality}

Survival of Hyalella azteca was significantly reduced in exposures to porewater from Sites 1, 4, 7, and 8 compared to laboratory control sediments (Table 1). However, survival and growth from solidphase exposures were not significantly reduced, although growth was lower at Sites 1, 4, and 8 compared to growth on sediments from the other sites tested. Basic chemistry values in porewater and overlying water from the solid-phase tests were generally within acceptable limits; however, ammonia was elevated in porewater from Sites 3, 4, 5, 6, 7, and 8 (Table 2). This elevation in porewater ammonia at these sites may have toxicological implications for freshwater mussels (Augspurger et al. 2003, Wang et al. 2007b,c), particularly for juvenile stages that spend more time feeding in porewater than adults (Neves et al. 1997, Reid et al. 1992, Yeager et al. 1994). The characteristics of the solid-phase sediments were also within acceptable ranges, except that the ratio of SEM:AVS exceeded the threshold value of 1 at Sites 2 and 4 (Table 3). SEM:AVS ratios 
Table 1. Toxicity measured as percent survival and growth of Hyalella azteca after exposure for $96 \mathrm{~h}$ to porewater and $28 \mathrm{~d}$ to solid-phase sediments collected from the Chipola River, May 2 and 3, 2006. *Significantly reduced compared to laboratory control $(\mathrm{p}<0.05)$

\begin{tabular}{|c|c|c|c|c|c|c|c|c|c|}
\hline \multirow{2}{*}{ Test parameter } & \multicolumn{8}{|c|}{ - Site } & \multirow{2}{*}{$\begin{array}{c}\text { Lab. } \\
\text { control }\end{array}$} \\
\hline & 1 & 2 & 3 & 4 & 5 & 6 & 7 & 8 & \\
\hline Porewater survival (\%) & $78^{*}$ & 92 & 98 & $58^{*}$ & 98 & 92 & $76^{*}$ & $32^{*}$ & 98 \\
\hline Sediment survival (\%) & 98 & 98 & 100 & 100 & 96 & 96 & 94 & 98 & 98 \\
\hline \multirow{2}{*}{$\begin{array}{l}\text { Sediment growth } \\
\text { (length in } \mathrm{mm}, \pm 1 \mathrm{SD} \text { ) }\end{array}$} & & & & & & & & & \\
\hline & $4.4 \pm 0.5$ & $4.6 \pm 0.4$ & $4.6 \pm 0.6$ & $4.3 \pm 0.5$ & $4.4 \pm 0.5$ & $4.8 \pm 0.4$ & $4.6 \pm 0.5$ & $4.3 \pm 0.4$ & $4.4 \pm 0.6$ \\
\hline
\end{tabular}

Table 2. Water chemical characteristics of porewater and overlying water from toxicity tests on porewater and solid-phase sediments from samples collected from the Chipola River, May 2 and 3, 2006 compared to a laboratory control

\begin{tabular}{|c|c|c|c|c|c|c|c|c|c|}
\hline \multirow{2}{*}{ Parameter } & \multicolumn{8}{|c|}{$\mathrm{Si}$} & \multirow{2}{*}{$\begin{array}{c}\text { Lab. } \\
\text { control }\end{array}$} \\
\hline & 1 & 2 & 3 & 4 & 5 & 6 & 7 & 8 & \\
\hline \multicolumn{10}{|l|}{ Porewater } \\
\hline Temperature $\left({ }^{\circ} \mathrm{C}\right)$ & 22.7 & 22.7 & 22.7 & 22.7 & 22.7 & 22.7 & 22.7 & 22.7 & 22.7 \\
\hline Dissolved oxygen $\left(\mathrm{mg} \mathrm{l}^{-1}\right)$ & 6.9 & 8.0 & 7.8 & 7.4 & 7.0 & 5.7 & 7.4 & 7.8 & 8.0 \\
\hline $\mathrm{pH}$ & 8.25 & 8.18 & 8.22 & 8.29 & 8.24 & 8.16 & 8.13 & 8.18 & 8.26 \\
\hline Conductivity $\left(\mu \mathrm{S} \mathrm{cm}^{-1}\right)$ & 536 & 319 & 721 & 492 & 644 & 527 & 486 & 385 & 446 \\
\hline Alkalinity $\left(\mathrm{mg} \mathrm{l}^{-1} \mathrm{CaCO}_{3}\right)$ & 280 & 186 & 400 & 292 & 398 & 318 & 282 & 228 & 102 \\
\hline Hardness $\left(\mathrm{mg} \mathrm{l}^{-1} \mathrm{CaCO}_{3}\right.$ ) & 247 & 187 & 422 & 275 & 344 & 201 & 229 & 134 & 145 \\
\hline Ammonia $\left(\mathrm{mg} \mathrm{l}^{-1} \mathrm{NH}_{3}\right)$ & 1.9 & 2.2 & 10.3 & 9.7 & 7.1 & 9.4 & 8.5 & 6.2 & 0 \\
\hline Chloride $\left(\mathrm{mg} \mathrm{l}^{-1}\right)$ & 11.6 & 2.75 & 14.66 & 2.84 & 3.13 & 3.34 & 3.08 & 1.73 & 32.3 \\
\hline Nitrate $\left(\mathrm{mg} \mathrm{l}^{-1}\right)$ & 3.1 & 0.0 & 0.0 & 0.0 & 0.0 & 0.0 & 7.0 & 0.0 & 0.0 \\
\hline Sulfate $\left(\mathrm{mg} \mathrm{l}^{-1}\right)$ & 27.09 & 1.35 & 5.47 & 17.96 & 24.80 & 2.66 & 3.12 & 24.25 & 88.36 \\
\hline Organic carbon $\left(\mathrm{mg} \mathrm{l}^{-1}\right)$ & 9.49 & 4.24 & 18.90 & 6.94 & 6.94 & 8.71 & 7.90 & 15.38 & 1.83 \\
\hline Inorganic carbon $\left(\mathrm{mg} \mathrm{l}^{-1}\right)$ & 61.87 & 44.00 & 104.50 & 71.84 & 95.66 & 74.50 & 68.85 & 55.36 & 23.86 \\
\hline Total carbon $\left(\mathrm{mg} \mathrm{l}^{-1}\right)$ & 71.4 & 48.2 & 123.4 & 78.8 & 102.3 & 83.2 & 76.8 & 70.7 & 25.7 \\
\hline \multicolumn{10}{|l|}{ Overlying water } \\
\hline Temperature $\left({ }^{\circ} \mathrm{C}\right)$ & 23.5 & 23.5 & 23.5 & 23.5 & 23.5 & 23.5 & 23.5 & 23.5 & 23.5 \\
\hline Dissolved oxygen $\left(\mathrm{mg} \mathrm{l}^{-1}\right)$ & 7.18 & 7.01 & 6.62 & 6.77 & 6.72 & 6.47 & 6.42 & 6.75 & 6.90 \\
\hline $\mathrm{pH}$ & 8.44 & 7.80 & 7.83 & 7.70 & 7.73 & 7.71 & 7.74 & 7.64 & 7.65 \\
\hline Conductivity $\left(\mu \mathrm{S} \mathrm{cm}^{-1}\right)$ & 312 & 334 & 325 & 314 & 318 & 313 & 320 & 297 & 286 \\
\hline Alkalinity $\left(\mathrm{mg} \mathrm{l}^{-1} \mathrm{CaCO}_{3}\right)$ & 90 & 92 & 90 & 86 & 86 & 82 & 88 & 74 & 80 \\
\hline Hardness $\left(\mathrm{mg} \mathrm{l}^{-1} \mathrm{CaCO}_{3}\right.$ ) & 120 & 110 & 122 & 119 & 118 & 121 & 121 & 120 & 118 \\
\hline Ammonia $\left(\mathrm{mg} \mathrm{l}^{-1} \mathrm{NH}_{3}\right)$ & 0 & 0 & 0.1 & 0.1 & 0 & 0 & 0.1 & 0.1 & 0 \\
\hline
\end{tabular}

$>1$ suggest that the metal concentrations in the sediments exceed the sulfides and may be biologically available to cause toxicity (Di Toro et al. 1992).

The highest concentrations of As and, to a lesser extent, $\mathrm{Ni}$ in porewater occurred at sites in the middle of the study range (Table 4). Concentrations of $\mathrm{As}, \mathrm{Cu}$, $\mathrm{Ni}, \mathrm{Pb}$, and $\mathrm{Zn}$ were elevated in sediments, especially at Sites 3, 4, 7, and 8 (Table 5). Although these concentrations were elevated over those at other sites on the river, they were not alarmingly high (Eisler 1988a,b, 1993, 1997, 1998, MacDonald et al. 2000). The total concentrations of these trace elements could contribute to a reduction in overall habitat quality at those sites where they are elevated; however, there were no statistically significant correlations between trace element concentrations and test metrics (survival or growth).
Benthic macroinvertebrate populations were quite similar throughout the study range, even though there was a marked increase from upstream to downstream in size (width, depth, and discharge) of the river (Table 6). The total number of taxa ranged from 32 to 56 , but no longitudinal trend was apparent (Vannote et al. 1980). The highest number of taxa was found at Site 5 (56 taxa), and the lowest, at Site 2 (32 taxa). Diversity of the benthic organisms was high throughout the study range, and dominance of individual taxa was fairly consistent throughout. There were some shifts in dominance of taxa from upstream to downstream (e.g. Ephemeroptera taxa), but this may have been influenced by differences in sampling efficiency. In general, no sites appeared to have the diminished benthic populations that would indicate stressful conditions. 
Table 3. Characterization (physical characteristics, acid volatile sulfides [AVS], and simultaneously extracted metals [SEM]) of sediments collected from the Chipola River, May 2 and 3, 2006 compared to a laboratory control. (-): no data available

\begin{tabular}{|c|c|c|c|c|c|c|c|c|c|}
\hline \multirow{2}{*}{ Parameter } & \multicolumn{8}{|c|}{ - Site } & \multirow{2}{*}{$\begin{array}{c}\text { Lab. } \\
\text { control }\end{array}$} \\
\hline & 1 & 2 & 3 & 4 & 5 & 6 & 7 & 8 & \\
\hline Moisture (\%) & 24.0 & 42.8 & 40.3 & 33.6 & 29.3 & 27.7 & 44.5 & 47.4 & 23.6 \\
\hline Total organic matter $(\%)$ & 2.4 & 5.4 & 4.7 & 2.3 & 1.4 & 0.6 & 6.7 & 4.9 & 0.0 \\
\hline Course organic matter (\%) & 1.0 & 4.0 & 4.0 & 2.0 & 1.0 & 0.0 & 6.0 & 5.0 & 0.0 \\
\hline Sand (\%) & 88 & 90 & 80 & 96 & 95 & 95 & 85 & 49 & 93 \\
\hline Silt (\%) & 1 & 5 & 10 & 0 & 2 & 3 & 9 & 29 & 7 \\
\hline Clay (\%) & 11 & 4 & 9 & 4 & 3 & 2 & 6 & 22 & 1 \\
\hline $\operatorname{AVS}\left(\mu \mathrm{mol} \mathrm{g} \mathrm{g}^{-1}\right)$ & 0.14 & 0.10 & 2.51 & 0.21 & 0.00 & 0.00 & 0.44 & 2.13 & 0.00 \\
\hline $\operatorname{SEM}\left(\mu \mathrm{mol} \mathrm{g}{ }^{-1}\right)$ & 0.10 & 0.14 & 0.20 & 0.87 & 0.10 & 0.06 & 0.26 & 0.52 & 0.02 \\
\hline SEM/AVS & 0.74 & 1.36 & 0.08 & 4.13 & - & - & 0.59 & 0.25 & - \\
\hline Copper $\left(\mathrm{ng} \mathrm{g}^{-1}\right)$ & 53 & 23 & 25 & 233 & 11 & 5 & 17 & 73 & 3 \\
\hline Cadmium $\left(\mathrm{ng} \mathrm{g}^{-1}\right)$ & 2 & 9 & 6 & 4 & 5 & 3 & 12 & 5 & 0 \\
\hline $\operatorname{Tin}\left(n g g^{-1}\right)$ & 3 & 1 & 1 & 3 & 1 & 1 & 1 & 2 & 1 \\
\hline Mercury (ng g $\left.{ }^{-1}\right)$ & 1 & 1 & 0 & 0 & 0 & 0 & 0 & 0 & 0 \\
\hline Lead $\left(\mathrm{ng} \mathrm{g}^{-1}\right)$ & 100 & 82 & 192 & 140 & 65 & 31 & 124 & 227 & 9 \\
\hline Zinc $\left(n g g^{-1}\right)$ & 116 & 132 & 208 & 1130 & 131 & 90 & 291 & 535 & 35 \\
\hline
\end{tabular}

Table 4. Concentrations of trace elements in porewaters from sediments collected May 2 and 3, 2006, from the Chipola River, Florida, compared to a laboratory control. BDL: analyte is below detection limits

\begin{tabular}{|c|c|c|c|c|c|c|c|c|c|}
\hline \multirow{2}{*}{ Trace element } & \multicolumn{8}{|c|}{ Site } & \multirow{2}{*}{$\begin{array}{c}\text { Lab. } \\
\text { control }\end{array}$} \\
\hline & 1 & 2 & 3 & 4 & 5 & 6 & 7 & 8 & \\
\hline $\operatorname{Ag}\left(\mu \mathrm{l}^{-1}\right)$ & 0.28 & BDL & BDL & BDL & BDL & BDL & BDL & BDL & BDL \\
\hline As $\left(\mu g l^{-1}\right)$ & 1.9 & 1.0 & 3.5 & 5.5 & 5.1 & 5.6 & 0.6 & 0.3 & 0.3 \\
\hline $\mathrm{Ca}\left(\mathrm{mg} \mathrm{l}^{-1}\right)$ & 93.0 & 70.6 & 161.6 & 103.2 & 121.2 & 70.0 & 80.4 & 45.8 & 43.6 \\
\hline $\mathrm{Cd}\left(\mu \mathrm{gl}^{-1}\right)$ & BDL & BDL & BDL & BDL & BDL & BDL & BDL & BDL & BDL \\
\hline $\mathrm{Cu}\left(\mu \mathrm{g} \mathrm{l}^{-1}\right)$ & BDL & BDL & 0.27 & BDL & BDL & BDL & BDL & BDL & 1.99 \\
\hline $\mathrm{Cr}\left(\mathrm{mg} \mathrm{l}^{-1}\right)$ & 0.7 & 0.1 & 0.7 & 0.6 & $\mathrm{BDL}$ & BDL & BDL & $\mathrm{BDL}$ & $\mathrm{BDL}$ \\
\hline $\mathrm{Fe}\left(\mathrm{mg} \mathrm{l}^{-1}\right)$ & 0.4 & 0.3 & 0.5 & 2.2 & 0.4 & 0.2 & 0.3 & 4.0 & 0.2 \\
\hline $\mathrm{K}\left(\mathrm{mg} \mathrm{l}^{-1}\right)$ & 1.8 & 0.9 & 4.9 & 1.9 & 1.5 & 1.4 & 0.8 & 2.0 & 6.3 \\
\hline $\mathrm{Hg}\left(\mu \mathrm{gl}^{-1}\right)$ & 2.48 & 2.40 & 0.44 & 1.38 & 1.37 & BDL & 0.21 & 1.97 & 1.42 \\
\hline $\operatorname{Mg}\left(\mathrm{mg} \mathrm{l}^{-1}\right)$ & 3.7 & 2.7 & 4.5 & 4.5 & 10.2 & 6.3 & 6.9 & 4.9 & 8.9 \\
\hline $\operatorname{Mn}\left(\mu \mathrm{gl}^{-1}\right)$ & 5.6 & 1.9 & 2.1 & 8.8 & 8.1 & 11.3 & 3.7 & 6.5 & 0.1 \\
\hline $\mathrm{Na}\left(\mathrm{mg} \mathrm{l}^{-1}\right)$ & 36.8 & 11.7 & 27.4 & 16.9 & 12.9 & 13.6 & 17.4 & 33.8 & 44.2 \\
\hline $\mathrm{Ni}\left(\mu \mathrm{g} \mathrm{l}^{-1}\right)$ & 3.56 & 2.92 & 4.52 & 3.88 & 3.46 & 0.96 & 2.14 & 1.84 & 1.40 \\
\hline $\mathrm{Pb}\left(\mu \mathrm{g} \mathrm{l}^{-1}\right)$ & 0.57 & 0.57 & 1.90 & 0.46 & 0.30 & $\mathrm{BDL}$ & 1.95 & 0.25 & 1.41 \\
\hline Se $\left(\mu \mathrm{g}^{-1}\right)$ & 45.0 & 50.8 & 44.2 & 46.6 & 53.6 & 54.8 & 49.0 & 50.8 & 62.6 \\
\hline $\mathrm{Zn}\left(\mu \mathrm{gl}^{-1}\right)$ & 206.0 & 121.2 & 350.0 & 41.4 & 97.8 & 47.2 & 1374.0 & 148.4 & 270.0 \\
\hline
\end{tabular}

\section{Risk estimation}

Sampling results showed little concern for ambient water quality. Data were compared to Florida's and Alabama's water quality standards, as well as the ammonia criterion that was recommended to the United States Environmental Protection Agency for the protection of freshwater mussels by Augspurger et al. (2003). In no case were water quality standards found to be exceeded, and all sites received a risk score of zero for ambient water quality. However, the samples represented single point and time measures and can- not be taken to indicate the general water quality conditions of the Chipola River, particularly under more variable flow conditions. Furthermore, water quality regulations involving numeric, threshold standards of this type do not take into account the interaction of different analytes that may increase toxicity. Toxicity testing of ambient waters is used to capture toxicity not expected from these individual ambient measures.

Sediment toxicity testing showed toxicity in the interstitial or porewater of the sampled sediments. Acute toxicity was only observed in these porewater tests. Whole sediments did not yield an acutely toxic 
Table 5. Concentrations ( $\mathrm{mg} \mathrm{kg}^{-1}$ ) of trace elements in sediments collected May 2 and 3, 2006, from the Chipola River, Florida, compared to a laboratory control. Values for $\mathrm{Cr}$ and Se are not available. BDL: analyte is below detection limits

\begin{tabular}{|c|c|c|c|c|c|c|c|c|c|}
\hline \multirow{2}{*}{ Trace element } & \multicolumn{8}{|c|}{ Site } & \multirow{2}{*}{$\begin{array}{c}\text { Lab. } \\
\text { control }\end{array}$} \\
\hline & 1 & 2 & 3 & 4 & 5 & 6 & 7 & 8 & \\
\hline $\mathrm{Ag}$ & BDL & BDL & BDL & BDL & BDL & BDL & $\mathrm{BDL}$ & BDL & BDL \\
\hline As & 0.47 & 0.61 & 1.19 & 0.87 & 0.43 & 0.28 & 1.04 & 1.53 & 0.19 \\
\hline $\mathrm{Ca}$ & 888 & 980 & 3446 & 704 & 1348 & 2056 & 10821 & 1246 & 11.68 \\
\hline $\mathrm{Cd}$ & 0.8 & 0.56 & 0.31 & 0.14 & 0.16 & 0.21 & 0.59 & 0.94 & 0.03 \\
\hline $\mathrm{Cu}$ & 1.49 & 2.12 & 2.78 & 4.27 & 0.98 & 0.43 & 2.50 & 7.75 & 0.20 \\
\hline $\mathrm{Fe}$ & 2407 & 1881 & 4060 & 2414 & 1562 & 1143 & 6250 & 124729 & 109 \\
\hline $\mathrm{K}$ & 31.9 & 35.1 & 34.1 & 46.6 & 42.0 & 28.4 & 61.1 & 251.1 & 17.4 \\
\hline $\mathrm{Hg}$ & 0.02 & 0.04 & 0.07 & 0.03 & 0.02 & 0.01 & 0.07 & 0.08 & 0.00 \\
\hline $\mathrm{Mg}$ & 57.1 & 83.4 & 131.9 & 185.4 & 577.9 & 1151 & 8816 & 1554 & 11.0 \\
\hline $\mathrm{Mn}$ & 62.1 & 128.0 & 81.9 & 68.4 & 80.3 & 120.8 & 126.3 & 152.5 & 1.4 \\
\hline $\mathrm{Na}$ & 8.92 & 10.87 & 12.05 & 10.03 & 12.05 & 18.37 & 46.64 & 14.59 & 14.25 \\
\hline $\mathrm{Ni}$ & 1.55 & 2.25 & 2.59 & 2.17 & 1.66 & 1.14 & 2.83 & 3.01 & 0.08 \\
\hline $\mathrm{Pb}$ & 7.90 & 6.18 & 11.1 & 5.5 & 3.9 & 1.8 & 7.9 & 11.5 & 0.8 \\
\hline $\mathrm{Zn}$ & 6.18 & 9.33 & 11.07 & 11.07 & 6.12 & 3.25 & 15.12 & 32.49 & 0.79 \\
\hline
\end{tabular}

Table 6. Relative abundance and associated metrics of in situ populations of benthic macroinvertebrates collected in the Chipola River, Florida, May 2 and 3, 2006. SCI: sequential comparison index

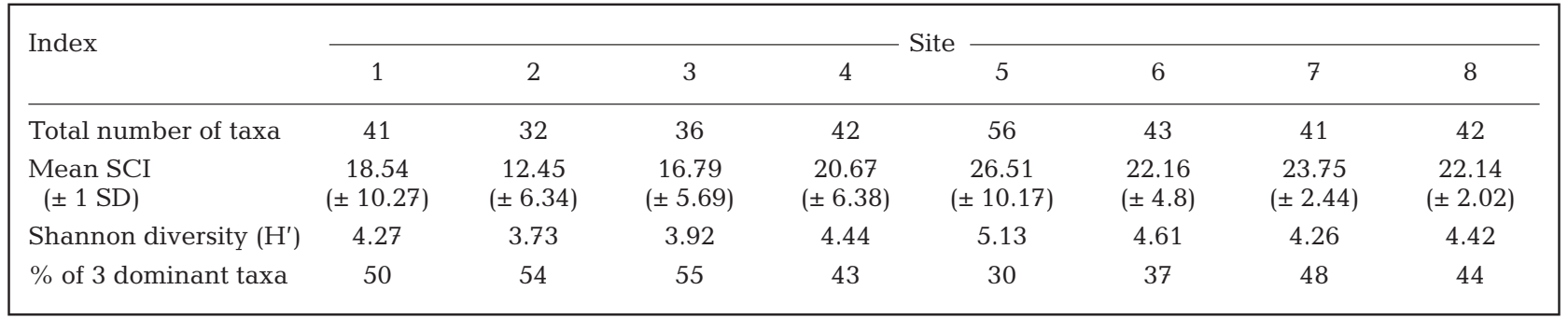

response, nor did the chronic whole-sediment assay based on growth. The matrix effects of whole sediment have been shown to decrease its toxicity relative to porewater, depending on the sediment composition (Winger \& Lasier 1993, 1995).

No sediment sample metal concentrations exceeded sediment quality guidelines for any site evaluated. All sites received a risk score of zero, indicating no risk from sediment metals. However, the samples represented single point and time measures and cannot be taken to indicate the overall sediment quality condition where metals are concerned.

Metals in sediment and porewater are not regulated at the state or federal level. For this reason, porewater metal concentrations were compared to Florida's and Alabama's water quality standards. The likelihood of metal exposure may be high for sensitive juvenile stages, because juvenile mussels spend more time feeding in the porewater environment (Reid et al. 1992, Yeager et al. 1994, Neves et al. 1997). Porewater metals found to exceed state standards designed to be protective of aquatic life included mercury, selenium, and zinc. While the water quality standard for mercury is a given number set to $\geq 0.012 \mu \mathrm{g} \mathrm{l}^{-1}$, the standard for many metals like selenium and zinc is derived from an algorithm based on water hardness. This estimation of risk based on porewater metal concentrations discounts the potential difference between surface water hardness and porewater hardness. This being the case, the influence that selenium or zinc may have on freshwater mussels exposed via porewater needs further investigation.

Risk for general sediment characteristics stemmed from the SEM:AVS ratio in the sediment samples. The SEM:AVS ratios were relatively high at Site 2 and particularly high at Site 4. A SEM:AVS > 1.0 indicates that the metal concentrations in the sediments exceed the sulfides and may be biologically available (Di Toro et al. 1992). This is particularly noteworthy with the presence of elevated porewater metals at all sites.

Non-metal porewater chemistry risk was associated with ammonia concentrations $\left(\mathrm{NH}_{3 i} \mathrm{mg} \mathrm{l} \mathrm{l}^{-1}\right)$ only. Ammonia concentrations were consistently measured to be above the recommended water quality criteria for ammonia as described by Augspurger et al. (2003). As with metals in porewater, there is a lack of regulation of ammonia in porewater. This risk to freshwater mussels is likely to be particularly pronounced for the juvenile stages that spend more time feeding in the porewater environment (Reid et al. 1992, Yeager et al. 1994, Neves et al. 1997). 
Combining (1) the data on ambient water chemistry and sediment chemistry, (2) laboratory toxicity, and (3) the in situ benthic assemblages indicated that Site 4 likely has impaired habitat quality and that Sites 1, 2, 7, and 8 may be impaired (Table 7, Fig. 3). Although there is not strong evidence (lack of consensus among data sets), the preponderance of information suggests possible habitat impairment at these sites. Based on the decision matrix, the elevated trace elements $(\mathrm{Zn}, \mathrm{Se}, \mathrm{Hg})$ in the porewater, irregular basic chemistry in the porewater $\left(\mathrm{NH}_{3}\right)$ and solid-phase sediment (SEM:AVS), and sediment toxicity (acute in porewater) are the major factors leading to these conclusions.

There is a particularly noteworthy co-occurrence of elevated porewater metals and a high SEM:AVS at Site 4 that may help explain the porewater toxicity observed there. At Site 2 these same porewater metal concentrations and the elevated SEM:AVS relationship may lead to porewater

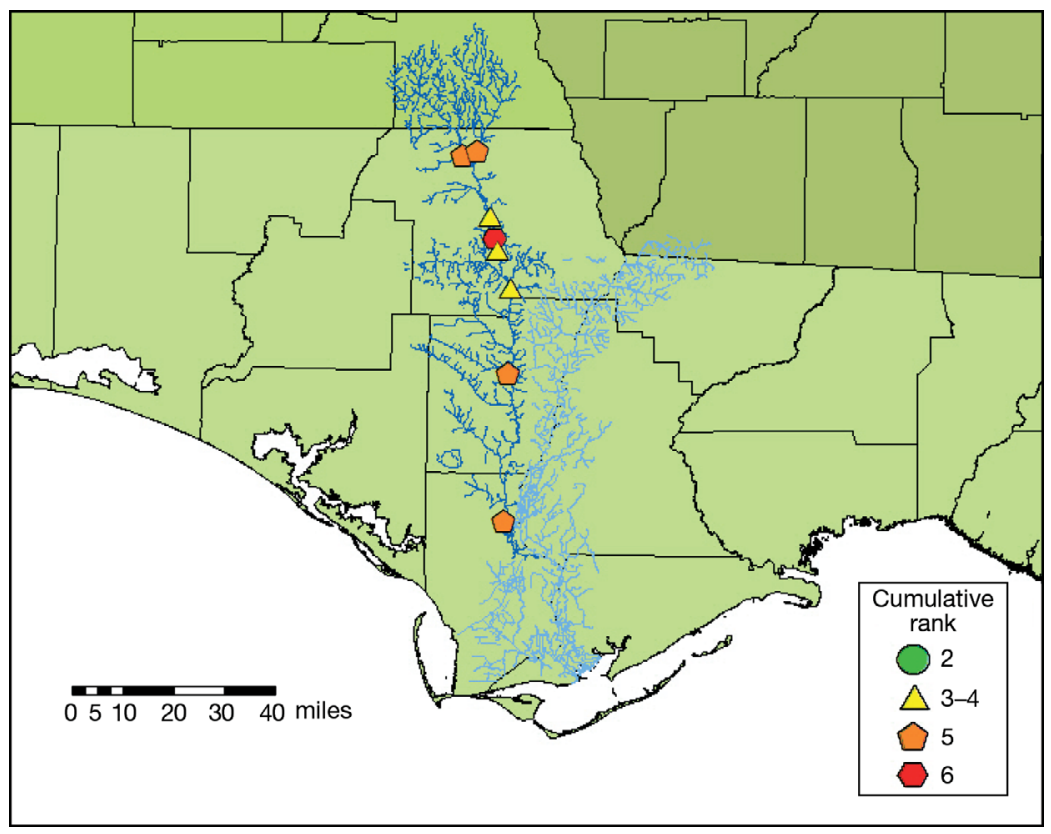

Fig. 3. Cumulative risk score estimated for freshwater mussel species in the Chipola River, Florida, based on sampling conducted during 2006 and 2007. Water quality standard violations, toxicity test differences from the controls, exceeded sediment analyte guidelines, elevated porewater contaminants, or abnormal in situ benthic macroinvertebrate assemblages each represented 1 risk point assessed. All assessed risk points were summed for each incidence of each parameter by site toxicity and is cause for further investigation. Although the lack of confirmation from the in situ benthic assemblages tends to somewhat diminish these categorizations of impairment, they may represent a different environmental compartment (more surficial) than those experienced by freshwater mussel species (within sediment and feeding in porewater as juveniles). Analytical investigations for organic chemicals associated with the sediments may provide additional insight into the habitat quality in the Chipola River, especially at Sites 1, 2, 7 , and 8.

\section{CONCLUSIONS}

All sites evaluated on the Chipola River during this survey showed at least 3 parameters that may be associated with risk to sediment-dependent aquatic life such as federally protected freshwater mussel species. Most sites showed $>3$ risk parameters. The high risk score of 6 (Site 4) included porewater toxicity, porewater metals, altered sediment chemistry (elevated SEM:AVS), and elevated porewater ammonia. The largest driving factor may be elevated metals in the

Table 7. Decision matrix summarizing habitat quality based on porewater and sediment toxicity, in situ benthic community structure, ambient water quality, contaminant concentrations in porewater and sediments, and basic chemistry of porewater, sediment, and overlying water in sediment tests. Analyses were performed on water and sediments from the Chipola River, Florida, during 2006 and 2007. Scores are summed to rank the estimation of cumulative risk

\begin{tabular}{|c|c|c|c|c|c|c|c|c|}
\hline \multirow{2}{*}{ Parameter } & & & & \multicolumn{2}{|c|}{ - Site } & \multirow[b]{2}{*}{6} & \multirow[b]{2}{*}{7} & \multirow[b]{2}{*}{8} \\
\hline & 1 & 2 & 3 & 4 & 5 & & & \\
\hline Toxicity & 1 & 0 & 0 & 1 & 0 & 0 & 1 & 1 \\
\hline Macroinvertebrates & 0 & 0 & 0 & 0 & 0 & 0 & 0 & 0 \\
\hline Water quality & 0 & 0 & 0 & 0 & 0 & 0 & 0 & 0 \\
\hline Sediment metals & 0 & 0 & 0 & 0 & 0 & 0 & 0 & 0 \\
\hline Porewater metals & 3 & 3 & 3 & 3 & 3 & 2 & 3 & 3 \\
\hline Sediment chemistry & 0 & 1 & 0 & 1 & 0 & 0 & 0 & 0 \\
\hline Porewater chemistry & 1 & 1 & 1 & 1 & 1 & 1 & 1 & 1 \\
\hline Cumulative rank & 5 & 5 & 4 & 6 & 4 & 3 & 5 & 5 \\
\hline
\end{tabular}


sediment porewater, where juvenile mussels tend to feed. Although these factors may pose a risk to the natural life history of freshwater mussels, related factors such as ambient water quality, whole-sediment metals, and in situ benthic macroinvertebrate communities did not show agreement with the elevated risk assessment at those sites.

The elevated risk areas did not correspond to an apparent decrease in species richness (number of federally listed threatened or endangered species) of imperiled taxa; however, abundance numbers and distribution of these species cannot be ascertained from the available database. Non-listed species richness, distribution, and overall abundance of species would be useful comparisons to make with these findings. However, these factors were not considered in this evaluation because of the limitations of the data currently available in the United States Fish and Wildlife Service Freshwater Mussel Database. Future plans include the quantification of populations of both federally protected and other freshwater mussel species in the northeastern Gulf of Mexico drainage area.

\section{LITERATURE CITED}

ASTM (American Society for Testing and Materials) (2007) Standard guide for conducting laboratory toxicity tests with freshwater mussels. E 2455-06. In: Annual Book of ASTM Standards, Vol 11.06. ASTM, West Conshohocken, PA, p 1378-1429

Augspurger T, Keller A, Black M, Cope W, Dwyer F (2003) Water quality guidance for protection of freshwater mussels (Unionidae) from ammonia exposure. Environ Toxicol Chem 22:2569-2575

Augspurger T, Dwyer FJ, Ingersoll CG, Kane CM (2007) Advances and opportunities in assessing contaminant sensitivity of freshwater mussel (Unionidae) early life stages. Environ Toxicol Chem 26:2025-2028

Bogan AE (1993) Freshwater bivalve extinctions (Mollusca: Unionidae): a search for causes. Am Zool 33:599-609

Brigham AR, Brigham WR, Gnilka A (eds) (1982) Aquatic insects and oligochaetes of North and South Carolina. Midwest Aquatic Sciences, Mahomet, IL

Bringolf RB, Cope WG, Eads CB, Lazaro PR, Barnhart MC, Shea D (2007a) Acute and chronic toxicity of technicalgrade pesticides to glochidia and juveniles of freshwater mussels (Unionidae). Environ Toxicol Chem 26:2086-2093

Bringolf RB, Cope WG, Mosher S, Barnhart MC, Shea D (2007b) Acute and chronic toxicity of glyphosate compounds to glochidia and juveniles of Lampsilis siliquoidea (Unionidae). Environ Toxicol Chem 26:2094-2100

Bringolf RB, Cope WG, Barnhart MC, Mosher S, Lazaro PR, Shea D (2007c) Acute and chronic toxicity of pesticide formulations (atrazine, chlorpyrifos, and permethrin) to glochidia and juveniles of Lampsilis siliquoidea. Environ Toxicol Chem 26:2101-2107

Brouwer H, Murphy TP (1994) Diffusion method for the determination of acid-volatile sulfides (AVS) in sediment. Environ Toxicol Chem 13:1273-1275

Cairns J Jr, Dickson KL (1971) A simple method for the biological assessment of the effects of waste discharges on aquatic bottom dwelling organisms. J Water Pollut Control Fed 43:455-472

Chapman PM (1990) The sediment quality triad approach to determining pollution-induced degradation. Sci Total Environ 97/98:815-825

Chapman PM (1996) Presentation and interpretation of sediment quality triad data. Ecotoxicology 5:327-339

Chapman PM, Anderson JA (2005) Decision-making framework for sediment contamination. Integr Environ Assess Manag 1:163-173

> Chapman PM, McDonald BG, Lawrence GS (2002) Weightof-evidence issues and frameworks for sediment quality (and other) assessments. Hum Ecol Risk Assess 8: 1489-1515

Daigle JJ (1991) Florida damselflies (Zygoptera): a species key to the aquatic larval stages. State of Florida, Department of Environmental Regulation Technical Series 11:1-12

Daigle JJ (1992) Florida dragonflies (Anisopterea): a species key to the aquatic larval stages. State of Florida, Department of Environmental Regulation Technical Series 12:1-28

Davies BF (1974) Loss-on-ignition as an estimate of soil organic matter. Soil Sci Soc Am Proc 38:150-151

Di Toro DM, Mahony JD, Hansen DJ, Scott KJ, Carlson AR, Ankley GT (1992) Acid volatile sulfide predicts the acute toxicity of cadmium and nickel in sediments. Environ Sci Technol 26:96-101

Eisler R (1988a) Arsenic hazards to fish, wildlife, and invertebrates: a synoptic review. US Fish Wildl Biol Rep 85 (1.12)

Eisler R (1988b) Lead hazards to fish, wildlife, and invertebrates: a synoptic review. US Fish Wildl Serv Biol Rep 85 (1.14)

Eisler R (1993) Zinc hazards to fish, wildlife, and invertebrates: a synoptic review. US Fish Wildl Serv Biol Rep 10, Washington, DC

Eisler R (1997) Copper hazards to fish, wildlife, and invertebrates: a synoptic review. Biol Sci Rep SGS/BRD// BSR-1997-0002, Biological Resources Division, US Geological Survey, Laurel, MD

Eisler R (1998) Nickel hazards to fish, wildlife and invertebrates: a synoptic review. Biol Sci Rep USGS/BRD/ BSR-1998-0001, Biological Resources Division, US Geological Survey, Laurel, MD

Epler JH (1996) Identification manual for the water beetles of Florida. Division of Water Facilities, Department of Environmental Protection, State of Florida, Tallahassee, FL

Epler JH (2001) Identification manual for the larval Chironomidae (Diptera) of North and South Carolina. Spec Publ SJ2001-SP13, Division of Water Quality, North Carolina Department of Environment and Natural Resources, Raleigh, NC

Epler JH (2006) Identification manual for the aquatic and semi-aquatic Heteroptera of Florida. Division of Water Resources Management, Department of Environmental Protection, State of Florida, Tallahassee, FL

FAC (Florida Administrative Code) (2004) State of Florida surface water quality standards system. FAC 62-302 and 62302.530. Tallahassee, FL

Fuller SLH (1974) Clams and mussels (Mollusca: Bivalvia). In: Hart CW Jr, Fuller SLH (eds) Pollution ecology of freshwater invertebrates. Academic Press, New York, p 215-273

Gillis PL, Mitchell RJ, Schwalb AN, McNichols KA, Mackie GL, Wood CM, Ackerman JD (2008) Sensitivity of the glochidia (larvae) of freshwater mussels to copper: assessing the effect of water hardness and dissolved organic carbon on the sensitivity of endangered species. Aquat Toxicol 88:137-145 
Goudreau SE, Neves RJ, Sheehan RJ (1993) Effects of wastewater treatment plant effluents on freshwater mollusks in the upper Clinch River, Virginia, USA. Hydrobiologia 252:211-230

Havlik ME, Marking LL (1987) Effects of contaminants on naiad mollusks (Unionidae): a review. Resource Publication 164, US Fish and Wildlife Service, Washington, DC

Hemming JM, Winger PV, Herrington SJ, Gierhart W, Herod H, Ziewitz J (2006) Water and sediment quality at mussel (Unionidae) habitats in the Ochlockonee River of Florida and Georgia. Endang Species Res 2:37-49

Hollert H (2006) Should the sediment quality triad become a tetrad, a pentad, or possibly even a hexad? J Soil Sed 6: $4-8$

Horne FR, McIntosh S (1979) Factors influencing distribution of mussels in the Blanco River of central Texas. Nautilus 94:119-133

Ingersoll CG, Ankley GT, Burton GA, Dwyer FJ, Hoke RA, Norberg-King TJ, Winger PV (1994) Methods for measuring the toxicity and bioaccumulation of sediment-associated contaminants with freshwater invertebrates. EPA/ 600/R-94/024, Office of Research and Development, US Environmental Protection Agency, Duluth, MN

Jacobson PJ, Farris JL, Cherry DS, Neves RJ (1993) Juvenile freshwater mussel (Bivalvia: Unionidae) responses to acute toxicity testing with copper. Environ Toxicol Chem 12:879-833

Keller AE (1993) Acute toxicity of several pesticides, organic compounds, and a wastewater effluent to the freshwater mussel, Anodonta imbecillis, Ceriodaphnia dubia, and Pimephales promelas. Bull Environ Contam Toxicol 51: 696-702

Keller AE, Ruessler DS (1997) The toxicity of malathion to unionid mussels: relationship to expected environmental concentrations. Environ Toxicol Chem 16:1028-1033

Keller AE, Zam SG (1991) The acute toxicity of selected metals to the freshwater mussel, Anodonta imbecillis. Environ Toxicol Chem 10:539-546

MacDonald DD, Ingersoll CG, Berger TA (2000) Development and evaluation of consensus-based sediment quality guidelines for freshwater ecosystems. Arch Environ Contam Toxicol 39:20-31

March FA, Dwyer FJ, Augspurger T, Ingersoll CG, Wang N, Mebane CA (2007) An evaluation of freshwater mussel toxicity data in the derivation of water quality guidance and standards for copper. Environ Toxicol Chem 26: 2066-2074

> McPherson C, Chapman PM, deBruyn A, Cooper L (2008) The importance of benthos in weight of evidence sediment assessments - a case study. Sci Total Environ 394: 252-264

Miller WP, Miller DM (1987) A micro-pipette method for soil mechanical analysis. Commun Soil Sci Plant Anal 18:1-15

Mummert AK, Neves RJ, Newcomb TJ, Cherry DS (2003) Sensitivity of juvenile freshwater mussels (Lampsilis fasciola, Villosa iris) to total and un-ionized ammonia. Environ Toxicol Chem 22:2545-2553

Naimo TJ (1995) A review of the effects of heavy metals on freshwater mussels. Ecotoxicology 4:341-362

Neves RJ, Bogan AE, Williams JD, Ahlstedt SA, Hartfield PW (1997) Status of aquatic mollusks in the southeastern United States: a downward spiral of diversity. In: Benz GW, Collins DE (eds) Aquatic fauna in peril: the southeastern perspective. Spec Publ 1, Southeast Aquatic Research Institute, Lenz Design and Communications, Decatur, GA, p 43-85

> Newton TJ (2003) The effects of ammonia and freshwater unionid mussels. Environ Toxicol Chem 22:2543-2544
Newton TJ, Bartsch MR (2007) Lethal and sublethal effects of ammonia to juvenile Lampsilis mussels (Unionidae) in sediment and water-only exposures. Environ Toxicol Chem 26:2057-2065

Newton TJ, Allran JW, O'Donnell JA, Bartsch MR, Richardson WB (2003) Effects of ammonia on juvenile unionids (Lampsilis cardium) in laboratory sediment toxicity tests. Environ Toxicol Chem 22:2554-2560

NNMCC (National Native Mussel Conservation Committee) (1998) National strategy for the conservation of native freshwater mussels. J Shellfish Res 17:1419-1428

Parrish FK (ed) (1975) Keys to water quality indicative organisms of the southeastern United States. Office of Research and Development, US Environmental Protection Agency, Cincinnati, $\mathrm{OH}$

Pennak RW (1978) Fresh-water invertebrates of the United States, 2nd edn. John Wiley \& Sons, New York

Pescador ML, Richard BA (2004) Guide to the mayfly (Ephemeroptera) nymphs of Florida. Division of Water Resources Management, Department of Environmental Protection, State of Florida, Tallahassee, FL

Plafkin JL, Barbour MT, Porter KD, Gross SK, Hughes RM (1989) Rapid bioassessment protocols for use in streams and rivers - benthic macroinvertebrates and fish. EPA/440/4-89/001, Office of Water, US Environmental Protection Agency, Washington, DC

Pluchino ES (1984) Guide to the common water mite genera of Florida. State of Florida, Department of Environmental Regulation Technical Series 7:1-45

Poole RW (1974) An introduction to quantitative ecology. Series in Population Biology. McGraw-Hill, New York

Reid RGB, McMahon RF, Foighil DO, Finnigan R (1992) Anterior inhalent currents and pedal feeding in bivalves. Veliger 35:93-104

Richter BD, Braun DP, Mendelson MA, Master LL (1997) Threats to imperiled freshwater fauna. Conserv Biol 11:1081-1093

SAS Institute (1990) SAS user's guide, Version 6. SAS Institute, Cary, NC

SAS Institute (2007) SAS user's guide, Version 9.1.3. SAS Institute, Cary, NC

Sparks RE, Sandusky MJ (1981) Identification of factors responsible for decreased production of fish food organisms in the Illinois and Mississippi Rivers. Final Report 3291-R, Illinois Natural History Survey River Research Laboratory, Havana, IL

Thompson FG (2004) An identification manual for the freshwater snails of Florida. Florida Museum of Natural History, University of Florida, Gainesville, FL

USEPA (United States Environmental Protection Agency) (2002) National recommended water quality criteria: 2002. EPA-822-R-02-047, USEPA, Washington, DC

USFWS (US Fish and Wildlife Service) (2003) Recovery plan for endangered fat threeridge (Amblema neislerii), shinyrayed pocketbook (Lampsilis subangulata), gulf moccasinshell (Medionidus penicillatus), Ochlockonee moccasinshell (Medionidus simpsonianus), and oval pigtoe (Pleurobema pyriforme); and threatened chipola slabshell (Elliptio chipolaensis), and purple bankclimber (Elliptoideus sloatianus). US Fish and Wildlife Service, Atlanta, GA

Vannote RL, Minshall GW, Cummins KW, Sedell JR, Cushing CE (1980) The river continuum concept. Can J Fish Aquat Sci 37:130-137

- Wang N, Augspurger T, Barnhart MC, Bidwell JR and others (2007a) Intra- and interlaboratory variability in acute toxicity tests with glochidia and juveniles of freshwater mussels (Unionidae). Environ Toxicol Chem 26:2029-2035 
Wang N, Ingersoll CG, Hardesty DK, Ivey CD and others (2007b) Acute toxicity of copper, ammonia, and chlorine to glochidia and juveniles of freshwater mussels (Unionidae). Environ Toxicol Chem 26:2036-2047

Wang N, Ingersoll CG, Greer IE, Hardesty DK and others $(2007 \mathrm{c})$ Chronic toxicity of copper and ammonia to juvenile freshwater mussels (Unionidae). Environ Toxicol Chem 26:2048-2056

Williams JD, Warren ML, Cummings KS, Harris JL, Neves RJ (1993) Conservation status of freshwater mussels in the United States and Canada. Fisheries 18:6-22

Wilson DM, Naimo TJ, Wiener JG, Anderson RV, Sandheinrich MB, Sparks RE (1995) Declining populations of the fingernail clam Musculium transversum in the upper Mississippi River. Hydrobiologia 304:209-220

Winger PV, Lasier PJ (1993) Sediment toxicity testing: comparison of methods and evaluation of influencing factors.

Editorial responsibility: William Wallace,

Staten Island, New York, USA
In: Gorsuch JW, Dwyer FJ, Ingersoll CG, LaPoint TW (eds) Environmental toxicity and risk assessment, Vol 2. STP 1216, American Society for Testing and Materials, Philadelphia, PA, p 640-662

Winger PV, Lasier PJ (1991) A vacuum-operated pore-water extractor for estuarine and freshwater sediments. Arch Environ Contam Toxicol 21:321-324

Winger PV, Lasier PJ (1995) Sediment toxicity in Savannah Harbor. Arch Environ Contam Toxicol 28:357-365

Yeager MM, Cherry DS, Neves RJ (1994) Feeding and burrowing behaviors of juvenile rainbow mussels, Villosa iris (Bivalvia: Unionidae). J N Am Benthol Soc 13: $217-222$

Zumwalt DC, Dwyer FJ, Greer IE, Ingersoll CG (1994) A water-renewal system that accurately delivers small volumes of water to exposure chamber. Environ Toxicol Chem 13:1311-1314

Submitted: June 12, 2008; Accepted: September 22, 2008 Proofs received from author(s): November 26, 2008 